\title{
Detection of GAD65 autoantibodies of type-1 diabetes using anti-GAD65-abs reagent produced from bovine brain tissue
}

\author{
Djoko Wahono Soeatmadji ${ }^{*}$, Aulanni'am ${ }^{f},{\text { Fatchiyah } \text { Fatah }^{\neq} \text {, Sutiman B. Sumitro }}^{\neq}$
}

\begin{abstract}
Abstrak
Secara klinis, diabetes tipe 1 (DM 1) mungkin tampak seperti diabetes tipe 2 dan kedua hal tersebut seringkali sulit untuk dibedakan. Hanya pemeriksaan petanda autoimun kerusakan sel $\beta$ yang dapat membedakan kedua keadaan klinis tersebut. Karena harganya yang amat mahal ( $\pm \$ 150 /$ pemeriksaan), pemeriksaan anti-GAD65-abs tidak dapat dilakukan secara rutin di sebagian besar atau bahkan di semua laboratorium di Indonesia. Oleh sebab itu, produksi reagen anti GAD65-Abs di Indonesia mungkin dapat mengurangi biaya dan meningkatkan kualitas pelayanan diabetes di Indonesia. Kami membuat reagen untuk mendeteksi anti-GAD65Abs dengan memanfaatkan otak sapi sebagai sumber enzim dalam 3 tahap. Tahap 1, mengisolasi dan memurnikan enzim GAD65 dari jaringan otak sapi, mengenali sifat-sifat fisika dan kimiawi, dan menggunakannya sebagai antigen primer untuk menstimulasi pembentukan anti-GAD65 di tikus Wistar. Tahap 2, memurnikan dan menggunakan anti-GAD65 hasil pemurnian sebagai antibodi sekunder untuk menginduksi pembentukan anti-antibodi-GAD65 pada tikus Wistar dan kelinci. Tahap 3, memberi label fosfatase alkali dan peroksidase pada anti-antibodi-GAD65 dan menggunakannya untuk mengenali anti-GAD65-Abs diabetes tipe 1 yang sebelumnya telah diidentifikasi dengan menggunakan "kit" komersial. Reagen anti-antibodi-GAD65 yang diproduksi di laboratorium kami dapat mengenali anti-GAD65-abs yang sebelumnya telah dideteksi oleh "kit" komersial. (Med J Indones 2005; 14: 197-203)
\end{abstract}

\begin{abstract}
Clinically, type 1 diabetes may presents as type 2 diabetes which sometimes not easily differentiated. Perhaps only autoimmune markers of $\beta$-cells destruction could differentiate those two clinical conditions. Due to extremely high cost ( \$150/test), examination of anti-glutamic acid decarboxylase-65 auto-antibodies (anti-GAD65Abs) may not be routinely performed in most, if not all, clinical laboratories in Indonesia. Hence, the production of anti-GAD65 Abs reagent in Indonesia may reduce the cost and improve the quality of diabetes care in Indonesia. We produce reagent to detect anti-GAD65-Abs using bovine brain tissue as source of GAD enzyme in 3 steps. Step 1, isolation, purification of GAD65 from bovine brain tissue and used it as a primary antigen to stimulate the generation of anti-GAD65 antibodies in Wistar rat. Step 2, the purified GAD65 antibodies were than used as a secondary antibody to induce the production of anti-anti-GAD65-antibodies in Wistar rat and rabbit. Step 3. Labeling anti-antiGAD65-antibodies with alkaline phoshpatase and peroxidase, and detecting anti-GAD65Abs previously detected using commercial kit. The anti-anti-GAD65antibodies reagent produced in our laboratories successfully identify anti-GAD65-Abs of type 1 diabetic patients previously detected with commercial reagent. (Med J Indones 2005; 14: 197-203)
\end{abstract}

Keywords: GAD, type-1 Diabetes

\section{Background and objective}

Type 1 diabetes may appear as type 2 diabetes and clinically those two conditions are not easily

\footnotetext{
* Diabetes and Endocrinology Section, Internal Medicine Department, Faculty of Medicine Brawijaya University, Malang, Indonesia

${ }^{f}$ Department of Chemistry, Mathematic and Natural Sciences Faculty, Brawijaya University, Malang, Indonesia

F Department of Biology, Mathematic and Natural Sciences Faculty, Brawijaya University, Malang, Indonesia
}

differentiated. ${ }^{1}$ These patients are known as Slowly Progressive Type 1 Diabetes, Type $1 \frac{1}{2}$ Diabetes Mellitus, or Latent Autoimmune Diabetes in Adult (LADA). Kobayasi ${ }^{2}$ proposed that age of onset of Type $1 \frac{1}{2}$ diabetes is about $30-50$ years. Prevalence of type $1 \frac{1}{2}$ in Malang among non-obese adult onset diabetes was $22 \%{ }^{3}$ while other investigators found $16 \%-47 \% .{ }^{4}$ For differentiating those two conditions the only possible way is to identify the existence of autoimmune markers of $\beta$ cells destruction. These markers are : islet cell auto-antibodies (ICAs), insulin auto-antibodies (IAAs), anti-glutamic decarboxylase-65 auto-antibodies (anti-GAD65Abs), and anti-tyrosine 
kinase auto-antibodies (IA-2 and IA-2 $\beta$ ). Those autoimmune markers can also be used for detecting individuals with high risk of type $1 \mathrm{DM}$ and open the window for primary prevention measures. ${ }^{5}$ AntiGAD65Abs is an autoimmune marker of $\beta$-cell destruction with the highest sensitivity and specificity. Furthermore, it is known that anti-GAD65Abs can be detected up to 10 years before the onset appear (predisease phase) of the disease and remain positive long afterwards. Identification of anti-GAD65 Abs in adult onset diabetes individuals may be used as compelling evidence to start insulin therapy earlier.

Due to extremely high cost $( \pm \$ 150 /$ test $)$, examination of Anti-GAD65 Abs may not routinely be performed in most if not all clinical laboratories in Indonesia. Therefore in Indonesia, we thought it is necessary to have self-made reagent for detecting anti-GAD65-Abs with a more reasonable cost, so that the examination could be more widely done. Other scientists group in Brawijaya University also conduct a research to make probe for identification of HLA-DQB and DQA genes alleles which is susceptible to DM 1.

\section{METHODS}

This research is carried out at The Chemistry and Biology Laboratory, Faculty of MIPA (Mathematic and Natural Sciences) and The Biomedical Laboratory, Faculty of Medicine, Brawijaya University. Laboratory works were performed in three phases and each phase take one year. Raw materials of $\mathrm{GAD}_{65}$ enzyme were isolated from fresh bovine-brain tissue provided by Slaughterhouse of Malang. Research was funded by 'Penelitian Hibah Bersaing' 1997 - 2000. Serum of diabetic patients known to have positive anti-GAD ${ }_{65}-$ Abs were provided by PRODIA Laboratory. Those serum were collected from several PRODIA laboratory all over Indonesia, and anti-GAD65Abs were detected by ELISA method using available commercial human $\mathrm{GAD}_{65}$ recombinant reagent.

\section{Phase 1 ( $1^{\text {st }}$ year). Isolation, purification and GAD enzyme characterization}

a) GAD was isolated using Merrill's method ${ }^{6}$ and GAD activity testing was done using ion exchange resin micro-column from Matsuda ${ }^{7}$ and Robyt et al. ${ }^{8}$ GAD65 activity measured based on $\mathrm{CO} 2$ production of decarboxylation reaction using glutamic acid as a substrats. b) Crude enzyme $\mathrm{GAD}_{65}$ was purified using ammonium sulfate solution $0-60 \%$, continued by permeation gel chromatograph (Sephadex G-75); and continued by eletroelution technique of $65 \mathrm{kDa}$ band protein, which be confirmed by protein marker.

c) Optimal condition of purified GAD65 activity, including $\mathrm{pH}$, temperature, $\mathrm{Km}$, incubation time, molecule weight by SDSPAGE, isoelectric focusing (IEF), and influence of some interfering ions (activator and inhibitor) was done similar as phase (a).

Phase $2\left(2^{\text {nd }}\right.$ year). Biosyntesis of anti-GAD65-Abs and anti-anti-GAD6 -Abs

(a) Induction of anti-GAD65 in Rattus norvegicus. Rattus norvegicus was immunized using $\mathrm{GAD}_{65}$ (crude and purified) added with CFA (Complete Freund's Adjuvant) followed with booster immunization after 2 weeks and 1 month using $\mathrm{GAD}_{65}+$ IFA (Incomplete Freund's Adjuvant). ${ }^{9}$

(b) Recognizing anti-GAD 65-Abs. Anti-GAD65Abs in normal rats serum, streptozotocin diabetic rats and type 1 diabetes patients was recognized with SDS-PAGE and followed by Western Blotting using commercial anti-GAD65Abs reagent.

(c) Separating anti-GAD-65 Abs bands. AntiGAD65Abs bands were separated using electroelution technique and run with SDS-PAGE. Purified anti$\mathrm{GAD}_{65} \mathrm{Abs}$ were used as a antigen to stimulate biosynthesis of anti-anti-GAD65Abs in rabbit (Oryctolagus cuniculus). Anti-anti-GAD65Abs were than purified using SAS (saturated ammonium sulphate) $50 \%$ and recognized with SDS-PAGE $12 \%$ and confirmed by Western Blotting using serum of type 1 diabetes patient with positive anti-GAD65Abs.

Phase $3\left(3^{\text {rd }}\right.$ year). Anti-GAD65-Abs detection in serum of diabetic patient with anti-anti-GAD-65Abs.

Purified anti-anti-GAD ${ }_{65} \mathrm{Abs}$ isolated from here were labelled with alkaline phosphatase and peroxidase, and followed by blot-dot testing of anti-anti-GAD65Abs in serum of diabetic rat and type 1 diabetes patients with purified and labeled anti-anti-GAD65Abs.

\section{RESULTS}

Crude and purified $\mathrm{GAD}_{65}$ enzyme and $\mathrm{MM}$ electrophoregram with SDS-PAGE of GAD enzyme were 
shown in Figure 1. Protein bands with MM of $65 \mathrm{kD}$ were always positive in every enzyme fraction (either crude enzyme or pure enzyme). The GAD optimal activity condition were as follow: $\mathrm{pH} 7,0$; temperature $37^{\circ} \mathrm{C}$; blocked by $\mathrm{Fe} 2+, \mathrm{Zn} 2+, \mathrm{Cu} 2+$ ions and stimulated by pyridoxal phosphate, respectively.

Figure 2 shows that crude and purified GAD enzyme used as primary antigens is able to induce antiGADAbs synthesis in normal rats and induced antiGAD65 is quite sensitive for recognizing enzyme peptides, including peptides with molecular mass $(\mathrm{MM})$ of $65 \mathrm{kDa}$ (Figure 3). Results of biosynthesis anti-anti-GAD $\mathrm{G}_{65}$ in rabbit immunized with purified anti-GAD65Abs as antigen and recognition of those anti-anti-GAD65-Abs with SDS-PAGE followed by Western Blotting in serum of normal rats, diabetic rats and patients with type 1 diabetes using commercial reagent of anti-GAD65Abs are shown in Figure 4. Anti-anti-GAD65Abs labeled with alkaline phosphatase and peroxidase can detect anti-GAD65Abs in serum of diabetic patients which already been identified by ELISA method using commercial kit of human recombinant GAD65. Labeling with alkaline phosphatase is better than peroksidase (Figure 5).

\section{DISCUSSION}

In adult age, type 1 diabetes patients do not always come with acute classic symptoms, which are severe hypoglycemia, spontaneous ketosis, and coma. It is not uncommon that the first manifestation of type 1 diabetes is similar with type 2 diabetes, which is first appear as stable and mild metabolic disorders, and slowly show the symptoms of absolute insulin deficiency. The only way to differentiate between type 2 diabetes and slowly progressing type 1 diabetes could only be identification of auto-antibodies markers of $\beta$ cells in patients serum.

\section{Autoimmune markers of $\beta$ cells damage}

Markers of $\beta$ cell damage through autoimmune mechanism, are : islet cell auto-antibodies (ICAs), insulin auto-antibodies (IAAs), anti glutamic acid decarboxylase-65 auto-antibodies (anti-GAD65-Abs), anti tyrosine kinase auto-antibodies (IA-2 and IA$2 \beta) .{ }^{1}$ One or more of those autoimmune markers are found in $80-90 \%$ new DM 1 patients. Anti-GAD65Abs is the most sensitive and specific autoimmune markers. Furthermore it is also known that in type 1 DM, anti-GAD65Abs can be detected long before (up to 10 years) the disease is clinically manifest, thus giving a chance in primary prevention actions to prevent the manifestation of the disease.

The ability to detect the existence of autoimmune markers can also be applied as a solid base to start insulin therapy in adult diabetes which starting to show clinical signs of metabolic decompensation though diet therapy and hipoglycemic oral drugs have been administered.

However, laboratory examination for detecting autoimmune markers are not routinely done in most of laboratory in Indonesia and if it is done, the cost is very expensive.

It is believed that early insulin therapy in autoimmune type $1 \mathrm{DM}$ with slow manifestation said to have good effect, which is retarding the destruction rate of $\beta$ cells pancreas.

Glutamic acid decarboxylase (GAD) enzyme belongs to liase enzyme group and active in dividing the bonds of $\mathrm{C}-\mathrm{C}, \mathrm{C}-\mathrm{O}, \mathrm{C}-\mathrm{N}$ and the elimination of carboxyl cluster. According to Tinamaiya, ${ }^{12}$ GAD is a catalyst in the formation of $\gamma$-amino butiric acid (GABA). This enzyme can be isolated from plants, microorganisms, mammals brain tissue, and $\beta$ cells of Langerhans in pancreas. $^{13}$

\section{Anti-GAD65Abs (Anti-GAD65-Autoantibodies)}

Baekkeskov et al in 1982 (from: Cristie ${ }^{11}$ ) reported their success in identification of islet cells components which are recognized by antibody in IDDM patients, by means of immunoprecipitation to detect antibody binding to islet cells protein. The main protein which is specifically recognized by antibody of diabetic patient later is named as $64 \mathrm{~K}$-antigen.

In diagnosis, about $80 \%$ of type $1 \mathrm{DM}$ patients have antibody that can recognize the $64 \mathrm{kD}$-antigen. The antibody is also a very special marker to predict the onset of type $1 \mathrm{DM}$ in the future. Afterward, 64antigen is an enzyme, which is glutamic acid decarboxylase (GAD). This discovery was not directly in DM patients, but in Stiff-man Syndrome (SMS). SMS is characterized with progressive rigidity of the muscles which followed by painful spasm because of the disorder in neuronal inhibitory system which works through GABA ( $\gamma$-amino butiric acid). The antibody of GAD can be detected in $60 \%$ of SMS 
patients. Furthermore is known that SMS is an autoimmune disease, and GAD is the main autoantigen. All of SMS patients which have GAD antibodies also have ICA, and $30 \%$ of those patients also suffer from IDDM. Further research proved that $64 \mathrm{~K}$-antigen is equivalent to GAD islet. ${ }^{12}$

Now it is already known that GAD is expressed in many kinds of isoform. Two main isoforms are 65 and $67 \mathrm{kDa}$ (GAD-65 dan GAD-67), which already been cloned and sequenced ;the results showed that those two are the product of 2 different genes. ${ }^{12}$

In human, GAD-65 gene is located in $10^{\text {th }}$ chromosome, and GAD-67 in $2^{\text {nd }}$ chromosome. Those two isoform have different sequences in the first 100 amino acid from $\mathrm{N}$-terminus, but have high similarity level in the remainder of the amino acids.

The junction between those two regions (the first 100 amino acids and the remainder of amino acids) is the major target of many kinds of proteolytic enzymes (proteolytic hot spot). Amino acid sequences show little homologous with other protein molecules. Even that, either GAD-65 or GAD-67, in several places (amino acids 250-273 for GAD-65 and 253-281 for GAD-67) show similarity with P2-coxackievirus B4 protein. Some studies show the connection between infection of coxackievirus B4 with the emerging of IDDM. The mimicry of P2-C coxackievirus B4 protein molecules and GAD could possibly related in induction of autoimmune response to GAD. ${ }^{11}$

GAD-67 is a hydrophilic and soluble molecule, while GAD-65 in its mature form is a hydrophobic molecule, related to membrane; in neuronal cells this enzyme is related with synapses vesicles and in $\beta$ cells pancreas is related with synaptic-like vesicles'. The difference in sequence of the first 100 amino acids between GAD-65 and GAD-67 could responsible to the compartmentialization of the two isoforms.

Even though the homologous level of amino acid sequences between GAD-65 and GAD-67 is high, the auto-antibodies ability in binding with those two isoforms is very different. In human GAD-65 is the main isoform, while GAD-67 only recognized by the antibody in $20 \%$ of IDDM patients. Furthermore it is known that the portions which have enough amount of GAD-67 binding is because of the partial crossreactivity with GAD-65. Even though a vast research about GAD prevalence in general population have not been carried out yet, but other research show that in general population the prevalence is low $(<5 \%)$. ${ }^{12}$

\section{Crude GAD enzyme, pure GAD enzyme}

These results show that bovine brain tissue can be used as an alternative source of glutamic acid decarboxylase enzyme. Electrophorese with SDSPAGE to measure molecule mass (MM) of crude enzyme proteins and also phased purified enzyme with ammonium sulphate and gel permeation column (Sephadex G-75) consistantly shows $65 \mathrm{kDa}$ protein band (Figure 1).

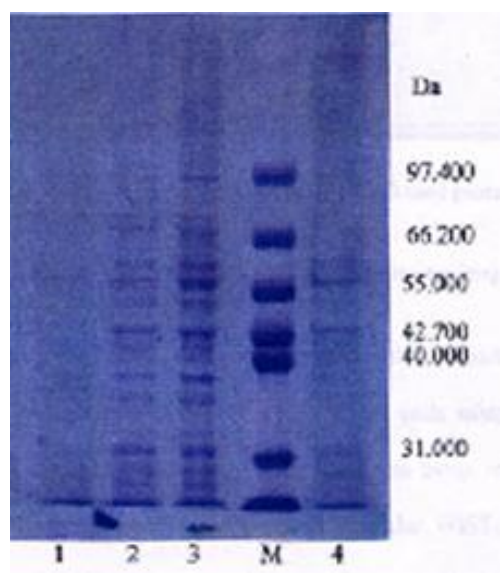

Figure 1. Result of crude and purified GAD enzyme electroforegram. $M$ (protein marker); (1) GAD from purification with SAS 30-60\%; (2) SAS fraction $0-30 \%$; (3) crude enzyme; (4) SAS fraction $30-60 \%$

\section{Anti-GAD65Abs}

Crude enzymes and also purified GAD enzymes, as primary antigen can be used to induce anti-GAD65 synthesis in Wistar rat. Immunization to induce antiGAD65 synthesis was done in Wistar rat by injection of $1500 \mu \mathrm{L}(250 \mu \mathrm{g}$ GAD65 enzyme + CFA (Complete Freund's Ajuvant), and repeated after 2 weeks with $250 \mu \mathrm{g}$ GAD65 enzyme + IFA (Incomplete Freund's Ajuvant) with ratio $1: 1$. The result from Western Blotting analysis shows that induced anti-GAD65 is quite sensitive in recognizing GAD enzyme peptides, including peptide with $65 \mathrm{kDa}$ which is known as the immune marker of type 1 diabetes. Anti-GAD synthesized by Wistar rat also recognized by antibody in patients serum which is known to have anti-GAD65Abs which have been detected using ELISA method and commercial reagent (recombinant DNA GAD65) and serum 
sterptozotocine diabetic Wistar rat. This shows the similarity in response between anti-GAD synthesized by normal rat induced with GAD enzyme from isolation, with anti-GAD peptides from IDDM patients \{with anti-GAD65Abs $(+)\}$. Hence, it can be concluded that GAD enzyme isolated from bovine brain and the triggered antibody have the same cross reaction.

The result from running SDS-PAGE of pure antiGAD isolated from rat serum 1 month and 2 month after injection shows protein bands. Anti-GAD65 bands is separated by electroelusion and after running with SDS-PAGE the bands results are shown in Figure 2.

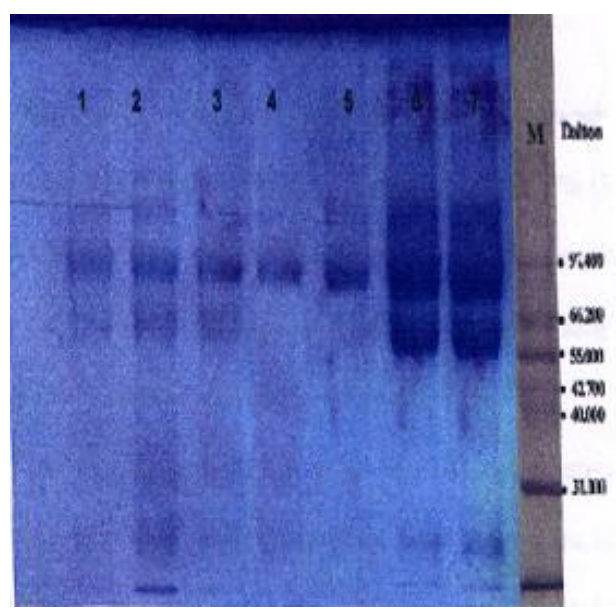

Figure 2. Result from electroforegram of pure anti-GAD65 from rat serum inducted by GAD enzyme

\section{Biosynthesis of anti-anti-GAD65Abs}

In order to produce anti-anti-GAD65Abs, immunization of local hare is carried out by injecting purified antiGAD65 as secondary antigen. Isolation of anti-antiGAD65Abs is done in 1 week, 2 weeks, 1 month, and 2 months after injection, and followed by purification using saturated ammonium sulphate (SAS 50\%).

The result of running SDS-PAGE 12\% hare serum which have been immunized shows the existence of anti-anti-GAD65Abs bands (confirmed with protein markers) (Figure 3). The $65 \mathrm{kDa}$ band is the result of hare response to immunization with anti-GAD. The $65 \mathrm{kDa}$ bands have been proved to appear consistently. The result of running SDS-PAGE anti--anti-GAD65 with different induction duration shows that $65 \mathrm{kDa}$ protein band is thicker than others protein bands.
In order to know the analogous between GAD enzyme isolated from bovine brain with anti-GAD65Abs (from GAD65 induction) and anti-anti-GAD65Abs (from anti-GAD65 induction), Western Blotting examination is carried out. The result of the examination with serum of IDDM patient with anti-GAD65Abs (+) have a positive reaction. The positive anti-GAD65Abs serum before that have been detected with ELISA method using human recombinant GAD65 kit produced by Boehringer Mannheim; those positive serum have anti-GADAbs titer 1.05-2.770.

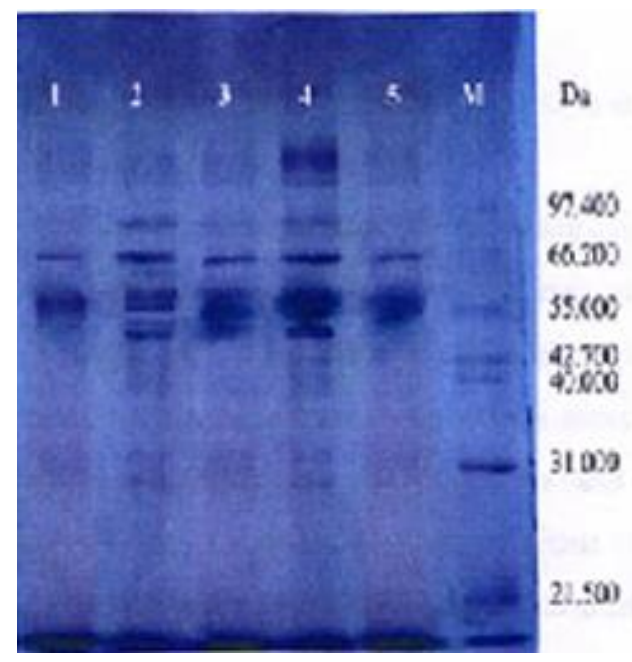

Figure 3. Result from electroforegram of Anti-anti-AD65 Abs from induction with anti-GAD65Abs. $M$ (marker); 1, 2, 3, 4, 5 Anti-GADAbs from different kinds of induction

From Western Blotting, only in treated rat group (Figure 4) appear some bands which suspected as 65 $\mathrm{kDa}$ antibody. Band thickness pattern is depended on the time of induction and the material quality (the antigen). The result of Western Blotting test to IDDM patient serum with anti-GAD65Abs $(+)$ shows that GAD enzyme isolated with bovine brain can be recognized by autoantibodi-GAD65 of diabetic human and also rat.

\section{Anti-anti-GAD65Abs labeling}

Anti-anti-GAD65Abs labeling from biosynthesis of laboratory animals is used to do Dot Blotting test in diabetic rat serum and IDDM patient with antiGAD65Abs (+), also done in different concentration of GAD enzyme (Figure 5). 


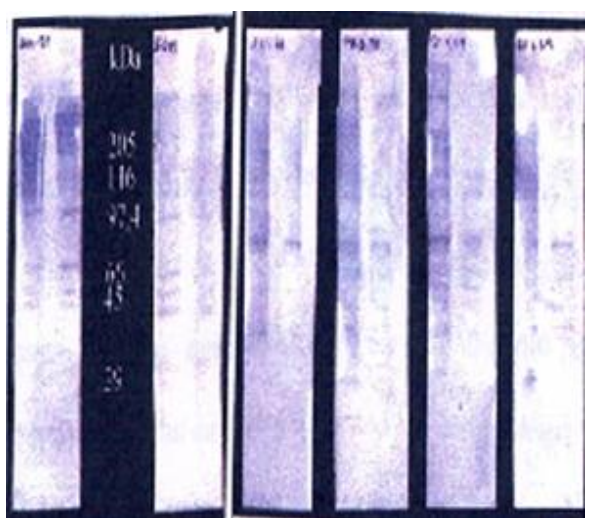

Figure 4. Western blotting in rat serum from induction with $G A D$ and serum of DM patient (anti-GAD65Abs positive)

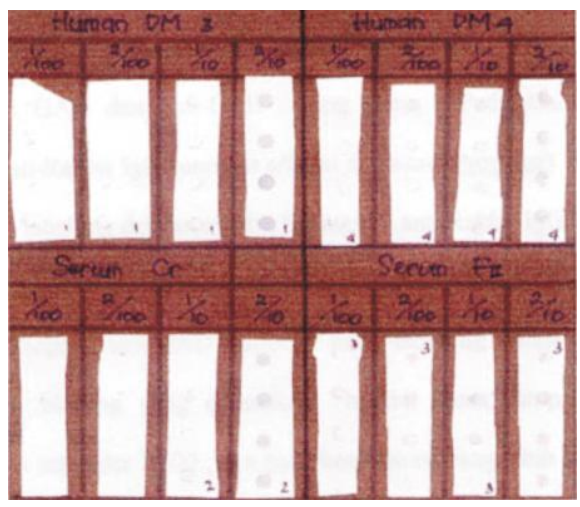

Information : $1 / 100,1 / 50,1 / 5$ are the concentration of antiantiGADAbs (FII, 1 month), Serum $\mathrm{Cr}$ : crude anti GAD; serum FII : pure anti GAD Fraction II.

Figure 5. Dot blotting serum of IDDM patient using anti-antiGADAbs labeled with alkaline phosphatase.

Labeling is done with alkali phosphatase and peroxidase. Positive reaction from the result of Dot Blotting shows the success of labeling, because the detected serum derived from DM patients serum with antiGAD65Abs (+) which have been tested by ELISA. Labeling result using alkali phosphatase is more stable than peroxydase which is quickly faded. The higher the concentration of GAD enzyme used in the test, the thicker the Dot Blotting colour will be. From the result of Dot Blotting, concentration of GAD enzyme used is chosen (2/10 dilution) with different antiGAD65 concentration. The result of Dot Blotting test with anti-GAD65Abs concentration 2/100 already shows positive reaction.

\section{CONCLUSION AND SUGGESTION}

(1) GAD enzyme, either the crude or the purified ones can induce anti-GAD65Abs biosynthesis in Wistar rat, and isolated and purified anti-GAD65 from Wistar rat can induce anti-anti-GAD65Abs biosynthesis in local hare.

(2) Using Western Blotting method it can be proved that GAD can be recognized by anti-GAD in Wistar rat, serum of IDDM patient with anti-GAD65Abs (+). Using Dot Blotting method, Anti-antiGAD65Abs which have been labeled with alkali phosphatase have positive reaction with serum of IDDM patient with anti-GAD65Abs (+).

(3) This phenomenon shows that GAD enzyme isolated from bovine brain tissue can be developed into reagent for detecting anti-GAD65Abs in IDDM.

(4) More quantity of serum sample of IDDM with anti-GAD65Abs (+) is needed to determine the cut-off of reagent concentration from the production above.

\section{Acknowledgment}

This study was supported by The Directorat Research Development and Community Service, Directorate General High Education, Department of National Education and the result has received patent from the Directorate General Visibility Right and Intellectual, Department of Justice and Human Rights Indonesia number HC-H3.02.P01.015.5188/2003.

Special thanks to Prodia Laboratory for providing serum of diabetic patient with positive anti-GAD65Abs and David for translating this article to English.

\section{REFERENCE}

1. The Expert Committee. Report of the Expert Committee on the Diagnosis and Classification of Diabetes Mellitus. Diabetes Care 2000; 23 (Suppl.1): S4 - S19.

2. Kobayashi T. Slowly Progressive Type 1 Diabetes. In : Turtle, editor. Diabetes in The New Millenium. The Endocrinology and Diabetes Research Foundation of the University of Sydney. 1999; pp.101-4.

3. Arsana PM, Soeatmadji DW. Anti-GAD65Abs and Residual $\beta$-cell function in Diabetic Patients. Proceeding of PERKENI Congress. Bandung; 2000.

4. Pozilli P and Di Mario U. Autoimmune diabetes not requiring insulin at diagnosis (Latent Autoimmune Diabetes of Adult). Diabetes Care 2001; 24: 1460-7. 
5. Mehta V and Palmer JP. The Natural History of the IDDM Disease Process. In : Palmer JP, editor. Prediction, Prevention and Genetic Counseling in IDDM. Chichester: Palmer John Wiley \& Sons: 1997; pp.3-16.

6. Merrill JR, Tiinamaija T, William JK, Ian RM, Qiao-Yi C, Tamara M, Zimmet P and Ian RM. Autoantigen Properties of Native and Denaturated Glutamic Acid Decarboxylase : Evidence For a Conformational Epitope. Clinical Immunol and Immunopathol 1992; 71: 53-9.

7. Matsuda et al. Method in Enzymology Vol. VIII. New York: Academic Press Inc; 1972.pp. 202-4.

8. Robyt JF and White BJ. Biochemical Techniques : Theory and Practice. California: Cole Publishing company; 1987. pp. 116-8, 129-50, 292-318.
9. Artama TW. Antibodi Monoklonal, Teori, Produksi, Karakterisasi dan Penerapan. Yogyakarta: PAU Bioteknologi, UGM, 1996.

10. Boers J. Immunochemical Technique Laboratory Manual. Sidney: Academic Press, Harcout Brace Jovanovich Publisher. 1993.

11. Christie MR. Humoral Immune Markers: Antibodies to Glutamic Acid Decarboxylase. In: Palmer J, Editor. Prediction, Prevention and Genetic Counseling in IDDM. Chichester: John Wiley \& Sons; 1997. pp.77-96.

12. Schomburg D. Enzyme Handbook. German: SpringerVerlag; 1990.pp. 1-4. 